Sri Lanka J. Aquat. Sci. 20 (2) (2015): 31-38

\title{
Assessment of water pollution status in Uma Oya, Sri Lanka
}

\author{
K.A.W.S. Weerasekara ${ }^{*}$, A.A.D. Amarathunga, R.R.A.R. Shirantha, N. \\ Sureshkumar, W.D.N. Wickramaarachchi and S.A.M. Azmy
}

National Aquatic Resources Research \& Development Agency (NARA), Colombo 15, Sri Lanka

*Corresponding author (E mail: shyamalikaww@gmail.com)

\begin{abstract}
Uma Oya, which has the highest watershed of the Upper Mahaweli discharges into Rantambe reservoir. Uma Oya may have been polluted as it drains a large portion of agricultural lands. A preliminary study was conducted from April to October, 2007 sampling six randomly selected sites to determine the status of water quality of Uma Oya as baseline data. $\mathrm{pH}$, water temperature, dissolved oxygen, electrical conductivity and turbidity were measured in situ, whereas the processed water samples were brought to the laboratory to determine using standard methods, nitrate$\mathrm{N}$, nitrite-N, ammoniacal-N, ortho-phosphate, total suspended solids and chlorophyll-a content.

Many water quality parameters were within the tolerance limits for fish and other aquatic life. However, the Chlorophyll-a $(19.93 \pm 10.4 \mu \mathrm{g} / \mathrm{L})$ was slightly higher than the standard guidelines perhaps due to epilithic algae washed off from bed rocks under high water flow. Total suspended solids $(17.87 \pm 17.96 \mathrm{mg} / \mathrm{l})$ and turbidity $(37.84 \pm 59.88)$ were higher than the standard limits for fish and aquatic life, indicating high suspended solids transported by Uma Oya water. Further studies are required in relation to the cultivation pattern of the water shed to get a clear picture about Uma Oya.
\end{abstract}

Keywords: Water quality, Uma Oya, baseline data, upper Mahaweli

\section{Introduction}

The riverine habitats are among the major economically important and biologically rich ecosystems in Sri Lanka. The interrelationships between the various types of animals and plants in such unique habitats have an important and intimate bearing on fish populations ultimately contributing to national economy. One of the remarkable features of animal life in riverine habitats is its great diversity largely depending up on its physical and chemical environment. However, many riverine habitats of Sri Lanka rapidly altering through many anthropogenic activities such as improper use of agrochemicals, damming, discharging various waste materials, industrial effluents and deforestation (UNEP 2001). The report further stated that pollution, 
sedimentation, eutrophication, degradation of the ecosystem and excessive growth of aquatic weeds can be considered as the main threats to aquatic ecosystems in Sri Lanka. Also, recent studies suggested that many waters are deteriorating rapidly in Sri Lanka (Azmy et al. 2010; Gunawardena et al. 2010; Hewawasam 2010; Watawala et al. 2010).

Soil erosion is also of particular concern in the hill country where the upper watersheds of major rivers are located (SOE 2001). Typical land use changes in the hill country have a direct bearing on increasing soil erosion rates. The sediment yield study undertaken by NEDECO (1979) at a point in Peradeniya showed that the Mahaweli River carries 0.5 million tonnes of sediment per year. According to UNEP (2001), around 50\% of reservoir capacity at Rantambe would be lost within 12 years if no mitigation measures are taken into reduce sedimentation.

The river basin of the Uma Oya, one of the major tributaries of the Mahaweli River drains an area of $720 \mathrm{~km}^{2}$. It is originating from the Piduruthalagala and Thotopola Mountain tops and merges with the Mahaweli River at Rantambe reservoir (Chamikara and Harischandra 2012). The sub catchment represents diverse hydrological environment and land use patterns in the upper Mahaweli catchment, which is intercepting the land subjected to intensive agricultural practices and recent development activities impacting on water quality (Piyasiri 1995; Azmy et al. 2010; Amarathunga et al. 2013).

However, there is lack of baseline data on water pollution levels of Uma Oya. Therefore, the main objective of the study was to determine the status of water quality of Uma Oya as a baseline data set.

\section{Materials and Methods}

\section{Study Area}

Physico-chemical characteristics of the Uma Oya sub catchment were determined at monthly intervals from April to October, 2007 at six pre-selected sampling locations namely Ohiya (OH), Kirinda (KB), Mathetilla (MB), Welimada (WB), Ettampitiya (ET) and Uma Oya Mouth (UOM). Study area was selected using 1:50,000 scale topographic maps (Figure 1).

\section{Analysis of samples}

A total of 11 water quality parameters were measured to identify water pollution trend of the study area. In-situ analysis was carried out to measure $\mathrm{pH}$, water temperature, dissolved oxygen (DO), electrical conductivity (EC) and turbidity. Processed samples were brought to the laboratory to determine nitrate-N, nitrite-N, ammoniacal-N, orthophosphate and total suspended solids (TSS).

$\mathrm{pH}$ was measured using portable $\mathrm{pH}$ meter (Orion 260A), electrical conductivity, using Hanna portable multi range conductivity meter (HI 8733), dissolved oxygen content using Orion 830A portable dissolved oxygen meter and turbidity was measured using $\mathrm{HACH} 2100 \mathrm{P}$ portable turbidity meter. Laboratory analysis was conducted according to APHA (1998). Location and altitude of the study site are given in Table 1 . 
K.A.W.S. Weerasekara et al./Sri Lanka J. Aquat. Sci. 20 (2) (2015): 31-38

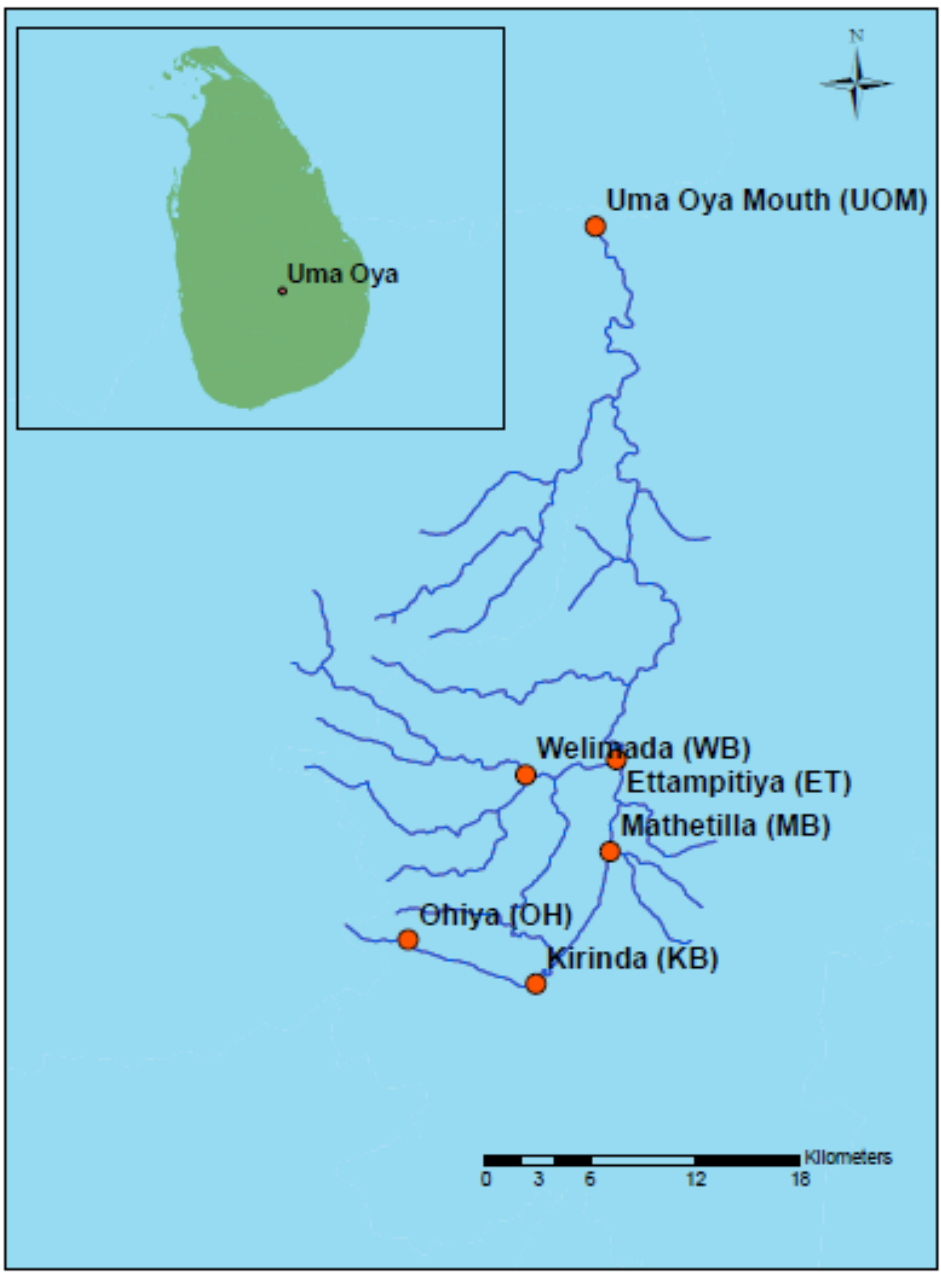

Figure 1. Sampling locations of the Uma Oya. Inset shows study area in Sri Lanka.

Table 1. Locations and altitudes of the sampling sites.

\begin{tabular}{llcl}
\hline \multicolumn{1}{c}{$\begin{array}{c}\text { Sampling } \\
\text { Location }\end{array}$} & \multicolumn{1}{c}{ Coordinates } & $\begin{array}{c}\text { Altitude } \\
(\mathrm{m})\end{array}$ & \multicolumn{1}{c}{ Remarks } \\
\hline Ohiya (OH) & $6^{\circ} 49^{\prime} \mathrm{N} ; 80^{\circ} 50^{\prime} \mathrm{E}$ & 1726 & upstream/reference \\
Kirinda (KB) & $6^{\circ} 47^{\prime} \mathrm{N} ; 80^{\circ} 54^{\prime} \mathrm{E}$ & 1175 & Intensive agriculture \\
Mathatilla (MB) & $6^{\circ} 51^{\prime} \mathrm{N} ; 80^{\circ} 57^{\prime} \mathrm{E}$ & 1048 & Agriculture in sloppy lands \\
Welimada (WB) & $6^{\circ} 54^{\prime} \mathrm{N} ; 80^{\circ} 54^{\prime} \mathrm{E}$ & 1035 & point source pollution \\
Ettampitiya (ET) & $6^{\circ} 54^{\prime} \mathrm{N} ; 80^{\circ} 57^{\prime} \mathrm{E}$ & 849 & $\begin{array}{l}\text { Tilapia fish breeding centre/ } \\
\text { Mini-hydro power station }\end{array}$ \\
& & & Downstream \\
Uma Oya Mouth & $7^{\circ} 11^{\prime} \mathrm{N} ; 80^{\circ} 56^{\prime} \mathrm{E}$ & 176 & \\
(UOM) & & & \\
\hline
\end{tabular}




\section{Analysis of Data}

The obtained data were computed and subjected to statistical analysis. Descriptive statistics for each water quality parameter were tested. Mean values of samples were analysed using descriptive statistics for all selected water quality parameters .The inter-sites mean variation were analysis by Kruskal-Wallis test. Water quality parameters were compared using analysis of variance (One-way ANOVA) with pairwise comparison for the significant differences. Differences were regarded to be at the significant level of 0.05 ( $p \leq 0.05$ ). Microsoft Excel 2003 and SPSS 20.0 packages were used for data analysis.

\section{Results}

Descriptive statistics for selected water quality parameters are given in Table 2 as average values for each sampling location. Additionally, mean total suspended solids $(17.87 \pm 17.96 \mathrm{mg} / \mathrm{l})$ and turbidity $(37.84 \pm 59.88)$ were higher than the standard limits for fish and aquatic life, indicating high suspended solids are transported by Uma Oya water.

Results of the ANOVA showed significant temporal differences in water temperature and phosphate levels. The selected parameters of statistical analysis are shown in Table 3. Based on the Kruskal-Wallis test, the two parameters were showed inter-site mean variation differences; water temperature $(\mathrm{F}=21.126, \mathrm{p}<$ $0.001)$ and Electrical Conductivity $(\mathrm{F}=14.524, \mathrm{p}<0.001)$ indicate statistically significance differences as determined by one-way ANOVA $(\mathrm{p}<0.05)$.

Table 2. Water quality parameters (mean \pm SE) in six sampling locations in Uma Oya $(\mathrm{n}=12)$. Ranges are given in parentheses. Abbreviations for sampling locations area as given in Table 1.

\begin{tabular}{lcccccc}
\hline \multicolumn{1}{c}{ Parameter } & $\mathrm{OH}$ & $\mathrm{KB}$ & $\mathrm{MB}$ & $\mathrm{WB}$ & $\mathrm{ET}$ & $\mathrm{UOM}$ \\
\hline Temperature & $17.8 \pm 2.94$ & $20.8 \pm 0.95$ & $24.6 \pm 1.76$ & $23.7 \pm 2.00$ & $24.2 \pm 2.08$ & $28.4 \pm 1.27$ \\
$\left({ }^{\circ} \mathrm{C}\right)$ & $(15.7-23.4)$ & $(19.6-22)$ & $(21-26.5)$ & $(21-26.7)$ & $(21.4-27.4)$ & $(27-30)$ \\
$\mathrm{pH}$ & $7.22 \pm 1.40$ & $7.43 \pm 1.04$ & $8.09 \pm 0.41$ & $8.05 \pm 0.20$ & $8.04 \pm 0.52$ & $8.19 \pm 0.50$ \\
& $(4.12-8.2)$ & $(5.32-8.05)$ & $(7.5-8.42)$ & $(7.8-8.32)$ & $(7.15-8.7)$ & $(7.48-8.83)$ \\
$\mathrm{DO}(\mathrm{mg} / \mathrm{L})$ & $7.06 \pm 1.78$ & $6.99 \pm 1.88$ & $6.33 \pm 1.36$ & $6.56 \pm 1.41$ & $6.09 \pm 1.15$ & $6.27 \pm 1.02$ \\
& $(4.8-10.4)$ & $(4.3-9.95)$ & $(4.5-7.88)$ & $(4.64-8.17)$ & $(4.56-7.59)$ & $(5.23-7.4)$ \\
$\mathrm{EC}(\mu \mathrm{S} / \mathrm{cm})$ & $76.6 \pm 15.5$ & $150.3 \pm 73.4$ & $114 \pm 56.0$ & $178 \pm 85.2$ & $130.28 \pm 67.7$ & $172.94 \pm 87.2$ \\
& $(61.4-229)$ & $(139-192)$ & $(116.5-152)$ & $(167.8-244)$ & $(144-174)$ & $(172-220)$ \\
Ammoniacal- & $0.22 \pm 0.33$ & $0.18 \pm 0.21$ & $0.18 \pm 0.18$ & $0.50 \pm 1.02$ & $0.06 \pm 0.07$ & $0.16 \pm 0.10$ \\
$\mathrm{~N}(\mathrm{mg} / \mathrm{L})$ & $(0.04-0.88)$ & $(0-0.49)$ & $(0.03-0.47)$ & $(0.01-2.59)$ & $(0.02-0.20)$ & $(0.01-0.29)$ \\
Nitrite-N & $0.016 \pm 0.004$ & $0.096 \pm 0.177$ & $0.059 \pm 0.072$ & $0.051 \pm 0.040$ & $0.023 \pm 0.016$ & $0.019 \pm 0.007$ \\
$(\mathrm{mg} / \mathrm{L})$ & $(0.01-0.02)$ & $(0.003-0.41)$ & $(0.01-0.21)$ & $(0.005-0.12)$ & $(0-0.05)$ & $(0.006-0.03)$ \\
Nitrate-N & $0.600 \pm 0.435$ & $0.714 \pm 1.035$ & $1.132 \pm 0.842$ & $0.815 \pm 0.908$ & $0.766 \pm 0.632$ & $1.041 \pm 0.716$ \\
$(\mathrm{mg} / \mathrm{L})$ & $(0.04-1.01)$ & $(0.001-2.21)$ & $(0.4-2.39)$ & $(0.03-2.14)$ & $(0.07-1.93)$ & $(0.39-2.29)$ \\
Phosphate & $0.015 \pm 0.004$ & $0.021 \pm 0.011$ & $0.039 \pm 0.029$ & $0.054 \pm 0.038$ & $0.040 \pm 0.024$ & $0.035 \pm 0.028$ \\
$(\mathrm{mg} / \mathrm{L})$ & $(0.01-0.02)$ & $(0.01-0.04)$ & $(0.02-0.08)$ & $(0.02-0.12)$ & $(0.02-0.08)$ & $(0.01-0.08)$ \\
TSS $(\mathrm{mg} / \mathrm{L})$ & $7.99 \pm 0.01$ & $12.48 \pm 0.04$ & $9.13 \pm 7.19$ & $34.63 \pm 25.13$ & $13.25 \pm 4.17$ & $22.13 \pm 26.99$ \\
& $(8.5-18.5)$ & $(11.5-67.5)$ & $(7.98-8.0)$ & $(2.0-19.0)$ & $(12.4-12.5)$ & $(6.0-62.5)$ \\
Turbidity & $5 \pm 7.32$ & $40 \pm 38.38$ & $58 \pm 125.59$ & $48 \pm 25.78$ & $52 \pm 60.53$ & $21 \pm 21.25$ \\
$(\mathrm{NTU})$ & $(1.46-21.9)$ & $(7.91-121)$ & $(8-343)$ & $(15.1-86)$ & $(15-159)$ & $(6.8-67.9)$ \\
\hline
\end{tabular}


K.A.W.S. Weerasekara et al./Sri Lanka J. Aquat. Sci. 20 (2) (2015): 31-38

Table 3. Analysis of Variance for selected water quality parameters.

\begin{tabular}{lrr}
\hline Parameter & F-value & F-prob. \\
\hline Temp. & 21.126 & 0.000 \\
pH & 1.634 & 0.177 \\
DO & 0.474 & 0.793 \\
EC & 14.524 & 0.000 \\
Ammoniacal-N & 0.638 & 0.672 \\
Nitrite-N & 0.952 & 0.462 \\
Nitrate-N & 0.344 & 0.881 \\
Phosphate & 2.223 & 0.073 \\
TSS & 0.951 & 0.484 \\
Turbidity & 0.899 & 0.499 \\
\hline
\end{tabular}

\section{Discussion}

Results revealed that the mean value of $\mathrm{pH}$, dissolved oxygen, electrical conductivity and nitrate- $\mathrm{N}$ were within the limit of proposed ambient water quality standards for inland waters of Sri Lanka (CEA 2001) for all sampling locations.

However, the overall water quality shows that the Ohiya sampling location of the upstream had comparatively good water quality than downstream sampling locations, showing an increasing trend of decreasing water quality from upstream to downstream. There are many annual cropping field and tea plantation in the upper catchment of Mahaweli, which have caused for the deterioration of water quality (Silva 1996; Watawala et al. 2010; Amarathunga et al. 2013). Similar land-use pattern existing in the Uma Oya catchment, and as such upstream sites may be subjected to less catchment land-use effects. The overall water quality of the Welimada, Mathatilla and Uma Oya mouth indicated comparatively high values for EC, Turbidity, TSS, Phosphate, Ammoniacal-N and Nitrate-N than other two locations. Furtherrmore, Welimada sampling location indicated high EC, Phosphate and TSS levels than other locations. TSS varies with sub-catchment area and land use.

Even though there is a statistically significant monthly difference shown in water temperature in the sampling locations, the average dissolved oxygen levels of all sampling locations appeared to be consistent as shown in Table 2. It may be mostly due to flowing water of Uma Oya stream since the dissolved oxygen levels in those types of water is more or less homogeneous (Dojlido and Best 1993).

Also, average Nitrite- $\mathrm{N}$ concentration in Uma Oya varied from 0.02 to 0.10 $\mathrm{mg} / \mathrm{l}$. According to Dojlido and Best (1993), nitrites are generally present at low concentrations in surface waters and there are no harmful impacts from nitrites to aquatic life or human consumption. Results revealed that average electrical conductivity ranged from 76.55 to $178.01 \mu \mathrm{S} / \mathrm{cm}$ in sampling locations. The lowest average EC was recorded from Ohiya $(76.55 \pm 15.47 \mu \mathrm{S} / \mathrm{cm})$. Comparatively high EC values recorded from Welimada $(178.01 \pm 85.21 \mu \mathrm{S} / \mathrm{cm})$ and Uma Oya mouth 
$(172.94 \pm 87.21 \mu \mathrm{S} / \mathrm{cm})$ showing an increasing values with decreasing altitude. Dharmarathne et al. (2008) also experienced this trend during his study carried out to assess water quality on Mahaweli River from head waters to downstream. It was also identified that Welimada sampling location indicate the highest EC value. It has been evident that this sampling location is subjected to open dumping of domestic wastes, opening of sewage outfalls and other untreated effluent outfalls directly into the stream. Thus, this high EC values may be due to contamination of stream waters due to these untreated substances. Recent report of UNEP (2001) emphasized that addition of sewage into stream waters would raise the conductivity due to various reasons such as presence of chloride, phosphate, and nitrate. Comparatively high phosphate values recorded from the Welimada sampling location further confirmed the situation. Gunawardena et al. (2010) stated that the direct solid waste disposal into water bodies and untreated dumping sites are some of the major causes of water pollution of Mahaweli River.

The average TSS of Welimada sampling location was $34.63 \pm 25.23 \mathrm{mg} / \mathrm{L}$ while Uma Oya Mouth recorded average of $22.13 \pm 27.0 \mathrm{mg} / \mathrm{L}$, suggesting the occurrence of soil erosion in the upstream areas. According to Hewawasam (2010), vegetables are grown extensively on the Upper Mahaweli Catchment without adhering to proper land management systems. Gunawardena et al. (2010), also stated that soil erosion in agricultural fields is the main cause for land degradation in Upper Mahaweli Catchment area causing reduction of land productivity and quality of the waters of downstream water bodies. This may further impact on aquatic invertebrate community in the Mahaweli Upper Catchment (PGIA 2010). The government report on an environmental profile of the Badulla District stated that problems of soil erosion and water pollution are widespread whereas deforestation, gives rise to a series of interrelated environmental problems. The report further emphasized that Welimada is one of the key areas which is subjected to encroachment on irrigation and other water reserves, cultivation of vegetables in commercial scale resulting adding of nutrient rich agrochemicals. It has been reported that the sediments due to soil erosion carries more Nitrate and Phosphate than that carries dissolved fraction in water (Amarasekara et al. 2013), and also heavy sediment loads from vegetable plots that come with runoff has increased the nutrient levels in the stream water. Hence, comparatively high values of Nitrate-N $(0.81 \pm 0.91 \mathrm{mg} / \mathrm{l})$, Ammoniacal-N $(0.50 \pm 1.02 \mathrm{mg} / \mathrm{L})$ and phosphate $(0.05 \pm 0.04 \mathrm{mg} / \mathrm{L})$ recorded in Welimada sampling location further indicates that the area may be subjected to water pollution due to agricultural activities carrying out in sloppy lands and in the upstream areas. However, the amount of discharged depend on the type of farming, the nature of the crops, the timing and the manner in which the fertilizer is used (Dojlido and Best 1993).

The highest Nitrate-N $(1.13 \pm 0.84 \mathrm{mg} / \mathrm{L})$ and turbidity $(58.22 \pm 125.59 \mathrm{NTU})$ values were recorded from Mathatilla among all selected sampling locations where the intensive agriculture activities are being practiced in steep slopes.

According to the results of the study, EC values ranged from 76.55 to 178.01 $\mu \mathrm{S} / \mathrm{cm}$, Nitrate-N ranged from 0.60 to $1.13 \mathrm{mg} / \mathrm{L}$ and Phosphate values ranged from 0.02 to $0.05 \mathrm{mg} / \mathrm{L}$ during the period of April to October 2007. However, according 
to the research findings of the Jayakody et al. (2011), EC values of the Uma Oya stream ranged from 91 to $249 \mu \mathrm{S} / \mathrm{cm}$, Nitrate-N ranged from 0.079 to $1.222 \mathrm{mg} / \mathrm{L}$ and Phosphate values ranged from 0.062 to $0.504 \mathrm{mg} / \mathrm{L}$ during February 2009 to January 2010 showing slightly increased values for all parameters. Urbanization with the development, overuse and misuse of inorganic fertilizers, increasing demand for agriculture may be the reasons for this trend.

In overall, it can be concluded that Uma Oya stream is currently subjected to sedimentation and the stream may be subjected to further the degradation in future, if mitigatory measures are not undertaken. Also, further studies are required in relation to the cultivation pattern, to calculate the sediment load of the water shed and for the space and time to get a clear picture about Uma Oya. Based on this preliminary study, it can be recommended that appropriate measures for land-use management should be in place to minimize soil erosion. Also, pollutant loading should be minimized from agricultural lands. For this purpose it would be important to conduct awareness programmes to educate local people about disposal of waste in such a way that prevents deterioration of the waters and sustainable utilization of water resources.

\section{Acknowledgements}

The authors would like to thank the competent technical assistance provided by the staff of Environmental Studies Division and Inland Aquatic Resources \& Aquaculture Division of NARA. Forest Department, Survey Department and Mahaweli Authority of Sri Lanka, are also greatly acknowledged for their assistance in numerous ways.

\section{References}

Amarathunga, A.A.D., K.A.W.S. Weerasekara, N. Sureshkumar, S.A.M. Azmy, W.D.N. Wickramaarchchi \& F. Kazama 2013. Behavior and loading of suspended sediment and nutrients from river basins in the hilly catena under intensive agriculture cropping: A case study in Upper Kotmale basin in Sri Lanka. Journal of Environmental Professionals Sri Lanka 2(2): 13-31.

APHA 1998. Standards Methods for the Examination of Water and Wastewater. 20th Edition. Washington, D.C, USA.

Azmy, S. A. M., A.A.D. Amarathunga, R.R.A.R. Shirantha \& K.A.W.S. Weerasekara 2010. Study of Nutrient Variation and Physico-chemical characteristics including bio-indicators of the Dik Oya Basin in Mahaweli Upper Catchment in Sri Lanka. Proceeding (Part-II Full Papers of the 15th International Symposium on Forestry and Environment, 26 to 27 November 2010, University of Sri Jayawardenapura, Nugegoda, Sri Lanka. 25-32 pp.

CEA 2001. Proposed Ambient Water quality Standards for Inland Waters Sri Lanka. Central Environmental Authority, Sri Lanka. 
Chamikara, S. \& S. Harischandra 2012. Uma Oya Multipurpose Developmental Project Violates Water Rights of the Uva Inhabitants. Environmental Conservation Trust. 7 p. http://www.lakdasun.org/forum/index.php? topic= 4935.0 (Accessed on 04 October 2013).

Dharmarathne, S., E.I.L. Silva \& N. Athukorale 2008. Water quality of riverrine and lacustrine habitats of Mahaweli River from headwaters to downstream. International Scientific Workshop on Riverscapes in Sri Lanka: Current Knowledge and future Challenges, Sri Lanka Foundation Institute, Colombo, pp. 21

Dojlido, J.R. \& G.A. Best 1993. Chemistry of water and water pollution. Ellis Horwood, New York.

Gunawardena, E.R.N., M.T.M. Maheesh, I.P.P. Gunawardana, E.A.S.K. Rathnapriya, N.G.T.S. Amarasekara \& S. Thrikawala 2010. Effects of socioeconomic and political factors in solid waste generation and water pollution. Symposium Proceedings of the Water Professional's Day, Crossing Boundaries Project. Post Graduate Institute of Agriculture and $\mathrm{Geo}-$ informatics Society of Sri Lanka.

Hewawasam, T. 2010. Effect of land use in the upper Mahaweli catchment area on erosion, landslides and siltation in hydropower reservoirs of Sri Lanka. Journal of National Science Foundation, Sri Lanka 38 (1): 3-14.

Jayakody, A.S., K.R. Munkittrick \& N. Athukorale 2011. Fish assemblage structure of two contrasting stream catchments of the Mahaweli river basin in Sri Lanka: Hallmarks of human exploitation and implications for conservation. The Open Conservation Biology Journal 5: 25-44.

NEDECO 1979. Mahaweli ganga development programme implementation strategy study. Mahaweli Development Board and NEDECO.

PGIA 2010. Interdisciplinary Education in Water Resources Management. Crossing Boundaries Project, Postgraduate Institute of Agriculture, University of Peradeniya. 20-25 pp.

Piyasiri, S. 1995. Eutrophication and blue green algal problem of Kotmale reservoir of Sri Lanka. 1-8 pp. In: K.H. Timotius \& F. Goltenboth (eds), Tropical Limnology. Volume II. Satya Wacana University Press, Salatiga, Indonesia.

Silva, E.I.L. 1996. Water quality of Sri Lanka. Institute of Fundamental Studies, Sri Lanka.

SOE 2001. Key National Environmental Issues [online]. Available from: http://www.rrcap.ait.asia/pub/soe/srilanka_land.pdf (Accessed 25 June 2012).

United Nations Environment Programme (UNEP) 2001. Sri Lanka: State of the Environment Report. Colombo, Sri Lanka. Available from: http://www.rrcap.unep.org/reports/soe/srilanka_toc.pdf (Accessed on 16 June 2011).

Watawala, R.C., J.A. Liyanage \& A. Mallawatantri 2010. Assessment of risks to water bodies due to residues of agricultural fungicide in intensive farming areas in the up-country of Sri Lanka using an indicator model. 69-76 pp. In: (A. Evans and K. Jinapala, eds) Proceedings of the National Conference on Water, Food Security and Climate Change in Sri Lanka, International Water Management Institute, Colombo. 